\title{
Charcot-Marie-Tooth Neuropathy X Type 1
}

National Cancer Institute

\section{Source}

National Cancer Institute. Charcot-Marie-Tooth Neuropathy X Type 1. NCI Thesaurus.

Code C129068.

Charcot-Marie-T ooth neuropathy that is inherited in an X-linked manner, and is associated with mutation(s) in the GJB1 gene, encoding gap junction beta-1 protein. The condition is characterized by moderate to severe motor and sensory neuropathy in males, and mild to no symptoms in females. 